\title{
Long intergenic non-protein-coding RNA 1567 (LINC01567) acts as a "sponge" against microRNA-93 in regulating the proliferation and tumorigenesis of human colon cancer stem cells
}

Xiaofeng $\mathrm{Yu}^{1}$, Lin $\mathrm{Mi}^{1}$, Jie Dong ${ }^{2}$ and Jian Zou ${ }^{1 *}$

\begin{abstract}
Background: Cancer stem cells (CSCs) are considered to be the major factor in tumor initiation, progression, metastasis, recurrence and chemoresistance. Maintaining the stemness and promoting differentiation of these cells involve various factors. Recently, long non-coding RNAs (IncRNAs) have been identified as new regulatory factors in human cancer cells. However, the function of IncRNAs in colon CSCs is still unknown.

Methods: Primary colon cancer cells were maintained in serum-free medium to form spheres and $C D 133^{+} / C D 166$ ${ }^{+} / \mathrm{CD}_{4} 4^{+}$spheroid cells were selected using FACS technique. Then we detected growth curve, colony formation, invasion and migration ability, and tumorigenicity of $\mathrm{CD} 133^{+} / \mathrm{CD} 166^{+} / \mathrm{CD} 44^{+}$cells. LOCCS-siRNA and PCDNA-LOCCS plasmid vectors were constructed and transfected to evaluate impact of the IncRNA. We also performed dual luciferase reporter assay to verify the interaction of LOCCS and miR-93.

Results: The research explored IncRNA expression and the regulatory role of novel IncRNAs in colon CSCs. Using the stem cell markers CD133, CD166 and CD44, we found a subpopulation of highly tumorigenic human colon cancer cells. They displayed some characteristics of stem cells, including the ability to proliferate and form colonies, to resist chemotherapeutic drugs, and to produce xenografts in nude mice. We also found an InCRNA, LOCCS, with obviously upregulated expression in colon CSCs. Knockdown of LOCCS reduced cell proliferation, invasion, migration, and generation of tumor xenografts. Furthermore, microRNA-93 (miR-93) and Musashi-1 mediated the tumor suppression of LOCCS knockdown.

Conclusions: There was reciprocal repression between LOCCS and miR-93. Research on mechanisms suggested direct binding, as a predicted miR-93 binding site was identified in LOCCS. This comprehensive analysis of LOCCS in colon CSCs provides insight for elucidating important roles of the IncRNA-microRNA functional network in human colon cancer.
\end{abstract}

Keywords: LINC01567, MicroRNA-93, Colon Cancer stem cells, Regulation

\footnotetext{
* Correspondence: apollozou@hotmail.com

${ }^{1}$ Department of Gastroenterology, Huadong Hospital Affiliated to Fudan

University, West Yan'an Road 221, Shanghai 200040, China

Full list of author information is available at the end of the article
} 


\section{Background}

Colorectal carcinoma (CRC) is in the third of malignant tumor in men and second in women, and in 2008, there were about 1.2 million new patients and 600,000 death cases [1]. Its incidence is still rising owing to aging populations with unhealthy eating habits. Despite efforts to improve clinical treatment, the prognosis of CRC patients has shown no marked progress in recent years. A small group of cells with stem cell properties, has been separated from CRC and they are referred to as CRC stem cells (CR-CSCs) [2]. These cells proliferate infinitely and differentiate into distinct cell types. Although rare in cancer tissue, CR-CSCs play a key role in the maintenance of tumor homeostasis. CSCs are proposed to be the source of malignancy and also the basis of progression, metastasis, recurrence and drug resistance $[3,4]$. Therefore, it is important to study the intrinsic mechanisms of CRC maintenance.

In the human genome, there are large amounts of noncoding RNA, including microRNAs (miRNAs) and long noncoding RNAs (lncRNAs, defined as $>200 \mathrm{nt}$ ). As a new modulator, lncRNAs have gained more and more attention for their roles in stem cell pluripotency, molecular scaffolding, transcriptional gene silencing and maintenance of DNA methylation/demethylation [5-8]. Many researchers have found that lncRNAs are dysregulated in various tumors, although their roles in tumor progression remain unknown [9-11]. LncRNAs are also key modulators of gene expression in stem cells and during carcinogenesis $[12,13]$. In addition, miRNAs have been reported to affect CRC tumorigenesis [14, 15]. LncRNAs have the ability to competitively inhibit miRNAs, and act as molecular "sponge". However, it remains unknown whether lncRNAs affect CRC progression by regulating miRNAs.

We previously isolated and characterized CR-CSCs from the cell line SW1116 (SW1116csc). Using miRNA arrays, we found 46 dysregulated miRNAs in SW1116csc cells in comparison with differentiated SW1116 cells. Among these miRNAs, 35 were overexpressed more than 1.5-fold, and 11 were downregulated. There was a 16.7 fold drop of miR-93 expression in SW1116csc, and the growth and coloning efficiency of SW1116csc were obviously inhibited by elevated expression of miR-93 [16]. However, lncRNAs that may competitively regulate miR-93 in CR-CSCs have not yet been identified.

\section{Methods}

\section{Patient sample preparation}

Tumorous colon tissues and corresponding adjacent non-tumoral colon tissue were collected from ten patients undergoing colon cancer surgery at Huadong Hospital, Shanghai, China. Written informed consents were obtained from all patients. Our protocol was approved by the Clinical Research Ethics Committee of Huadong Hospital. Clinicopathologic features of the ten colon cancer patients, including age, gender, and tumor site, stage, type and differentiation, are listed in Table 1.

\section{Primary cultures}

After washing with phosphate-buffered saline (PBS), colon samples were minced into $1.0 \mathrm{~mm}^{3}$ fragments and dissociated enzymatically with $0.25 \%$ trypsin-EDTA $(0.53 \mathrm{mM})$. Tumor/tissue fragments were incubated at $37{ }^{\circ} \mathrm{C}$ with pre-warmed enzyme for $100 \mathrm{~min}$. The cell suspension was then filtered and washed with SSM. After dissociation, the cells were purified using Ficoll-Hypaque density centrifugation. Finally, the recovered cell population was washed and resuspended in SSM and antibiotics (penicillin G $100 \mathrm{IU} / \mathrm{mL}$, streptomycin $100 \mathrm{mg} / \mathrm{L}$, metronidazole $1 \mathrm{mg} / \mathrm{L}$, amphotericin B $2.5 \mathrm{mg} / \mathrm{L}$, gentamicin $20 \mathrm{mg} / \mathrm{L}$ ) (Yihe Biological). Primary cells were seeded into 96-hole plates $\left(10,000\right.$ cells/hole) and cultured at $37{ }^{\circ} \mathrm{C}$ and $5 \%$ $\mathrm{CO}_{2}$ for 10 days.

\section{Culture of colon cancer spheres}

The serum-supplemented medium (SSM) contained RPMI 1640 medium and fetal bovine serum (10\% final concentration). Serum-free medium (SFM) consisted of DMEM/F12 (HyClone) supplemented with B27 (1:50; Gibco), $20 \mu \mathrm{g} / \mathrm{L}$ EGF (PeproTech), $10 \mu \mathrm{g} / \mathrm{L}$ bFGF (PeproTech), $10 \mu \mathrm{g} / \mathrm{L} \mathrm{LIF}$ (Chemicon), $2 \mathrm{mM}$ L-glutamine, $4 \mathrm{U} / \mathrm{L}$ insulin, $100 \mathrm{IU} / \mathrm{mL}$ penicillin G, and $100 \mathrm{mg} / \mathrm{L}$ streptomycin. Primary cultured colon cancer cells from surgery samples were digested with trypsin (Amresco) after washing with PBS and then cultured in SFM. After colon cancer spheres were generated, they were collected by centrifugation at $800 \mathrm{rpm}$, mechanically dissociated and cultured for progeny cell spheres.

\section{Flow cytometry}

Cell spheroids and normal primary cells were digested using trypsin and resuspended in PBS $\left(5 \times 10^{6} / \mathrm{mL}\right)$. Cells were incubated with FITC-conjugated anti-CD44 and PE-conjugated anti-CD133/CD166 monoclonal antibodies at $4{ }^{\circ} \mathrm{C}$ (30 min). The percentage of positive tumor cells was calculated by detection of fluorescence intensity of the molecules (CD44, CD133 and CD166). The FC500 flow cytometer from Beckman Coulter was used to analyze the samples.

\section{Western blotting}

Cells were added with lysing buffer consisted of $20 \mathrm{mM}$ Tris- $\mathrm{HCl}, 0.1 \%(w / v)$ Triton $\mathrm{X}-100,0.5 \%$ sodium deoxycholate, $1 \mathrm{mM}$ phenylmethylsulfonyl fluoride, $10 \mathrm{mg} / \mathrm{L}$ leupeptin, and $10 \mathrm{mg} / \mathrm{L}$ aprotinin. Then the mixture was centrifuged with $12,000 \times g$. BCA assay was used to measure total protein concentration. Protein of extract samples $(50 \mu \mathrm{g})$ was added to $10 \%$ SDS-PAGE following 
Table 1 Characteristics of the ten colon cancer patients participating in the present study and the tumor sample information

\begin{tabular}{|c|c|c|c|c|c|c|}
\hline Case & Gender & Age ranges (year) & Tumor site & Tumor stage & Tumor type & Differentiation \\
\hline 1 & M & $50-60$ & CS & I & $A C$ & Well \\
\hline 2 & M & $70-80$ & CS & IIIC & $A C$ & Moderately \\
\hline 3 & $\mathrm{~F}$ & $40-50$ & CA & $\| \mathrm{a}$ & $A C$ & Poorly \\
\hline 4 & M & $60-70$ & CS & IIlb & $A C$ & Poorly \\
\hline 5 & $\mathrm{~F}$ & $60-70$ & $C A$ & I & $A C$ & Moderately \\
\hline 6 & $\mathrm{~F}$ & $50-60$ & $C A$ & IV & $A C$ & Well \\
\hline 7 & F & $50-60$ & CS & Ila & $A C$ & Moderately \\
\hline 8 & M & $80-90$ & CA & IIlc & $A C$ & Well \\
\hline 9 & M & $60-70$ & CS & I & $A C$ & Well \\
\hline 10 & $\mathrm{~F}$ & $30-40$ & CA & IV & $A C$ & Poorly \\
\hline
\end{tabular}

CS colon sigmoideum, CA colon ascendens, AC Adenocarcinomas

PVDF electrophoresis (Invitrogen). Protein blots were probed with primary antibodies in 5\% milk in Tris-buffered saline at $4{ }^{\circ} \mathrm{C}$ overnight. The antibodies were against glyceraldehyde-3-phosphate dehydrogenase (GAPDH), Oct-4, Musashi-1 (MSI1), ABCG2, Sox2 and Klf4 (Santa Cruz Biotechnology).

\section{Cell proliferation and colony formation assays}

Spheroid cells and primary cultured cells $\left(1 \times 10^{4}\right)$ were seeded in 24-pore plate. $48 \mathrm{~h}$ later, trypan blue (Jianglai Bio) was added and cells were counted in triplicate over six weeks. For colony formation, spheres were digested with trypsin and resuspended in medium containing $0.3 \%$ agar. Then the mixture was plated onto a $0.6 \%$ agar bottom layer. Each culture dish contained $1 \times 10^{3}$ cells. After 14 days, clones with diameters larger than $0.5 \mathrm{~mm}$ were counted.

\section{Cell invasion and migration assays}

The ability of invasion and migration of CD $133^{+} / \mathrm{CD} 166$ ${ }^{+} / \mathrm{CD} 44^{+}$spheroid cells or primary cultured cells was evaluated using transwell chambers ( $8 \mu \mathrm{m}$ pore) polycarbonate membrane (Corning). Cells were seeded above the membrane. Matrigel (Becton Dickinson) was used to cover the top side of membrane for invasion assay and Matrigel-free for the migration assay. After culture at $37{ }^{\circ} \mathrm{C}$ for $48 \mathrm{~h}$, cells inside the upper chamber were removed. 95\% ethanol was used to fix the migrated and invaded cells under the membrane. After $0.2 \%$ crystal violet stained, the cells were counted under a microscope (five fields per well).

\section{Drug sensitivity assays}

Spheroid cells and primary cultured cells $\left(1 \times 10^{4}\right.$ per well) were seeded onto 96 -hole plates containing different concentrations of chemotherapeutic drugs or PBS. After $48 \mathrm{~h}$, Alamar Blue dye (Invitrogen, USA) was added in amounts equal to $10 \%$ of medium volume and cultured for $4 \mathrm{~h}$. Then absorbance of the mixture were measured using a microplate reader (Bio-Rad, Model 550) at $570 \mathrm{~nm}$ and $600 \mathrm{~nm}$.

\section{Establishment of tumor xenografts in nude mice}

For animal experiment, 6 week old female nude mice were used, which from the Weitong Lihua Laboratory Animal Center (Beijing, China). Mice were fed for one week in a specific pathogen-free animal cage before intervention. $\mathrm{CD} 133^{+} / \mathrm{CD} 166^{+} / \mathrm{CD} 44^{+}$spheroid cells were selected using flow cytometry as the experimental group. The primary cultured cells served as a control. Cells $\left(1 \times 10^{5}\right)$ were injected subcutaneously in the right flank of each mouse and observed the tumorigenicity. In the plasmid transfection assay, three groups of mice were injected with $\mathrm{CD} 133^{+} / \mathrm{CD} 166^{+} / \mathrm{CD} 44^{+}$cells containing different plasmids. Tumors were measured weekly using electronic calipers. The volume of tumor was calculated using the formula $V=(4 / 3) \pi x y^{2} . x$ is the half of the longest diameter (a) and $y$ is half of the perpendicular axis (b). The mice were sacrificed 63 days after inoculation, and $10 \%$ neutral formalin was used to fix the tumors. All animal experiments were approved by the Institutional Committee for Animal Research and followed the national guidelines for the care and use of laboratory animals (GB14925-2010).

\section{Real-time quantitative reverse transcription PCR}

Total RNA was isolated from cultured cells using the standard TRIzol method. 100 ng total RNA was used to synthesize cDNA with a SuperScript Reverse Transcriptase kit (Invitrogen). For PCR amplification system, $25 \mu \mathrm{L}$ reaction mixture was used containing $2 \mu \mathrm{g}$ of cDNA, $1 \mu \mathrm{L}$ primers and $12.5 \mu \mathrm{L} 2 \times$ SYBR Green PCR Master Mix. An ABI Prism 7000 real-time PCR machine (Applied Biosystems) was used for amplificationn reaction. The primer sequences were 5'-TGCTGGGGAAAGGAGATTGG-3' (sense) and 5' -AGCAGAAGTAAGGCACGAGG-3' 
(antisense) for LOCCS. PCR condition was denaturation at $95{ }^{\circ} \mathrm{C}$, and then 40 cycles of $95{ }^{\circ} \mathrm{C}(15 \mathrm{~s}) \rightarrow 60{ }^{\circ} \mathrm{C}$ (30 s) $\rightarrow 72{ }^{\circ} \mathrm{C}$ (3 s). Threshold cycle (CT) method was used to average and compare the real time values. The value of target RNA $\left(2^{-\Delta \Delta C T}\right)$ is normalized to $\beta$-actin expression reference $(\Delta C \mathrm{~T})$. The amount of target in untreated cells was set as 1.0. Experiments were performed in duplicate.

\section{LOCCS-small interfering RNA (siRNA) plasmid construction} and transfection

Three pairs of siRNA primers (Z1, Z2, Z3) targeting human LOCCS were synthesized and purified by Shanghai Haike Corporation. Annealing was performed in a $10 \mu \mathrm{L}$ reaction mixture including $4.5 \mu \mathrm{L}$ forward primer $(50 \mu \mathrm{M})$, $4.5 \mu \mathrm{L}$ reverse primer $(50 \mu \mathrm{M})$ and $1 \mu \mathrm{L}$ annealing buffer at $95{ }^{\circ} \mathrm{C}$ for $5 \mathrm{~min}$ and decreased to $30{ }^{\circ} \mathrm{C}$ gradually $\left(0.1^{\circ} \mathrm{C} / \mathrm{s}\right)$. BLOCK-iT U6 RNAi Entry Vector kit (Invitrogen) was used for ligation in a $10 \mu \mathrm{L}$ reaction volume containing $1 \mu \mathrm{L}$ annealed primers, $1 \mu \mathrm{L}$ pENTR/U6 plasmid, $1 \mu \mathrm{L}$ T4 ligase buffer, $1 \mu \mathrm{L}$ T4 ligase and $6 \mu \mathrm{L}$ deionized $\mathrm{H}_{2} \mathrm{O}$, and the reactions were placed at $16{ }^{\circ} \mathrm{C}$ for $2 \mathrm{~h}$. Then, $5 \mu \mathrm{L}$ of the ligated product was added to $100 \mu \mathrm{L}$ DH5X cell solution, and the mixture was placed at $4{ }^{\circ} \mathrm{C}$ for $10 \mathrm{~min}, 42{ }^{\circ} \mathrm{C}$ for $90 \mathrm{~s}$, and $4{ }^{\circ} \mathrm{C}$ for $5 \mathrm{~min}$. After $300 \mu \mathrm{L}$ Luria-Bertani medium was added, the mixture was shaked at $220 \mathrm{rpm}$ for $1 \mathrm{~h}$. Finally, transformants were transferred to kanamycin-containing plates at $37{ }^{\circ} \mathrm{C}$ overnight. Kanamycin-resistant clones were chosen, and the plasmids were isolated using the lyticase method. The inserted sequences in the plasmid were verified by DNA sequencing. Spheroid cells were transfected with $500 \mathrm{ng}$ of each of the three pENTR/U6-siLOCCS plasmids (Z1, Z2, Z3) with Fugene 6 Transfection kit (Roche). The transfected cells were harvested $48 \mathrm{~h}$ later, and expression level of miR-93 was mensurated using quantitative PCR.

\section{Construction of the pGL3M-miR-93 luciferase reporter plasmid}

For the luciferase reporter vector construction, the pre-miR93 sequence was synthesized with added XbaI sites by Shanghai Haike Corporation. The sequence was TGCTCGACTCTAGACTGGGGGCTCCAAAGT GCTGTTCGTGCAGGTAGTGTGATTACCCAACCTAC TGCTGAGCTAGCACTTCCCGAGCCCCCGGTCTAG AGCTGCTCG. The sequence was then inserted into a vector containing the pGL3 promoter upstream of the firefly luciferase (FLUC) reporter gene (Invitrogen). Sense (F:CTAGACtgggggctccaaagtgctgttcgtgcaggtagtgtgattaccca acctactgctgagctagcacttcccgagccccggT) and antisense (R:CTAGAccgggggctcgggaagtgctagctcagcagtaggttgggtaa tcacactacctgcacgaacagcactttggagcccccagT) primers were synthesized, and $4.5 \mu \mathrm{L}$ of each primer $(100 \mu \mathrm{M})$ and $1 \mu \mathrm{L}$ annealing buffer were placed at $95{ }^{\circ} \mathrm{C}$ for $5 \mathrm{~min}$, then
$25{ }^{\circ} \mathrm{C}$ for $30 \mathrm{~min}$. A $10 \mu \mathrm{L}$ solution containing $5 \mu \mathrm{L}$ annealed primers, $1 \mu \mathrm{L}$ PGL3-XbaI plasmid, $1 \mu \mathrm{L}$ T4 ligase buffer, $1 \mu \mathrm{L}$ T4 ligase and $2 \mu \mathrm{L}$ deionized $\mathrm{H}_{2} \mathrm{O}$ was placed at $16{ }^{\circ} \mathrm{C}$ for $2 \mathrm{~h}$. Then, $5 \mu \mathrm{L}$ ligated product was added to $100 \mu \mathrm{L} \mathrm{DH} 5 \times$ cell solution. The mixture was placed at $4{ }^{\circ} \mathrm{C}$ for $10 \mathrm{~min}, 42{ }^{\circ} \mathrm{C}$ for $90 \mathrm{~s}$, and $4{ }^{\circ} \mathrm{C}$ for $5 \mathrm{~min}$. After $300 \mu \mathrm{L}$ Luria-Bertani medium was added, the mixture was shaked at $220 \mathrm{rpm}$ for $1 \mathrm{~h}$. Finally, transformants were transferred to kanamycin-containing plates at $37^{\circ} \mathrm{C}$ overnight. Positive clones were chosen, and the inserted sequence in the plasmid was verified by DNA sequencing.

\section{Dual luciferase reporter assay}

$1 \times 10^{5}$ spheroid cells (per hole) were cultured in 24hole plates. $48 \mathrm{~h}$ later, they were cotransfected with the following combinations of plasmids. For endogenous LOCCS analysis (no exogenous LOCCS transfection), A: 400 ng pGL3M-miR-93 + 400 ng pENTR/U6-si-LOCCS +500 ng pRL-CMV; B: 400 ng pGL3M-miR-93 + 500 ng pRL-CMV; C: 400 ng pGL3M + 500 ng pRL-CMV; for exogenous LOCCS analysis, D: 400 ng pGL3M-miR$93+400$ ng pcDNA-LOCCS +500 ng pRL-CMV; E: 400 ng pGL3M-miR-93 + 400 ng pcDNA-LOCCS-T + 500 ng pRL-CMV; F: 400 ng pGL3M-miR-93 + 500 ng pRL-CMV. The pRL-CMV plasmid was cotransfected and used as a control. It contains a weak promoter region upstream from the Renilla luciferase gene and alone produces low levels of luminescence. The transfected spheroid cells were harvested $24 \mathrm{~h}$ later, and the luciferase content in lysed cells was measured using the Promega Dual Luciferase Reporter assay (Madison). FLUC and Renilla luciferase luminescence of the samples were measured in a luminometer (Promega GloMax 20/20 Luminometer). The result was expressed as fold change in cells receiving treatments relative to media control cells.

\section{Construction of pCDNA-LOCCS plasmid vectors}

The whole gene synthesis method was used to synthesize the LOCCS cDNA. For the total 2907 bp, 162 primers were designed and synthesized by Shanghai Haike Corporation, and each primer was then diluted to $10 \mu \mathrm{M}$. The primers were combined into groups of 20 (1-20, 19-40, 39-60, 59-80, 79-100, 99-120, 119-140, and 139-162) containing $10 \mu \mathrm{L}$ of each primer. Then, $5 \mu \mathrm{L}$ of the mixed primer solution was used for PCR amplification. The $50 \mu \mathrm{L}$ mixture included $5 \mu \mathrm{L} 10 \times$ buffer, $2 \mu \mathrm{L}$ $\mathrm{MgSO}_{4}, 1 \mu \mathrm{L}$ dNTPs, $5 \mu \mathrm{L}$ primer mix, $0.2 \mu \mathrm{L}$ PFU DNA polymerase, and $36.8 \mu \mathrm{L} \mathrm{H} \mathrm{H}_{2} \mathrm{O}$. The conditions for PCR: $95{ }^{\circ} \mathrm{C}$ (5 min), 30 cycles of $94{ }^{\circ} \mathrm{C}(30 \mathrm{~s}) \rightarrow 55{ }^{\circ} \mathrm{C}$ (30 s) $\rightarrow 72{ }^{\circ} \mathrm{C}(1 \mathrm{~min})$, and $72{ }^{\circ} \mathrm{C}(10 \mathrm{~min})$. When the amplification was completed, $2 \mu \mathrm{L}$ of the product was used for the amplification of eight larger fragments with the corresponding primers (primers 1 and 20, 19 and 40, 39 and 60, 59 and 80, 79 and 100, 99 and 120, 119 and 
140, 139 and 162). The $50 \mu \mathrm{L}$ PCR reaction mixture included $5 \mu \mathrm{L} 10 \times$ buffer, $2 \mu \mathrm{L} \mathrm{MgSO}_{4}, 1 \mu \mathrm{L}$ dNTPs, $2 \mu \mathrm{L}$ primers, $0.2 \mu \mathrm{L}$ PFU DNA polymerase, and $37.8 \mu \mathrm{L}$ $\mathrm{H}_{2} \mathrm{O}$. The PCR conditions were as previously. The PCR products were electrophoresed and then extracted from the gel slice using the AP-GX-50 AxyPrep/DNA Gel Extraction kit (Axygen). Finally, the eight larger extracted fragments were combined and $8 \mu \mathrm{L}$ used as template for a third round of PCR with primers 1 and 162 to synthesize the entire LOCCS CDNA. The PCR products were cloned into the pMD18-T vector (hereafter referred to as the LOCCS-ox plasmid). A $5 \mu \mathrm{L}$ reaction mixture containing $2 \mu \mathrm{L}$ PCR product, $0.5 \mu \mathrm{L}$ pMD18-T vector and $2.5 \mu \mathrm{L}$ of buffer, was cultured at $16{ }^{\circ} \mathrm{C}$ for $4 \mathrm{~h}$. Using electroporation, the plasmids were transfected into super-competent Escherichia coli DH5X and then seeded on ampicillin SOB medium. After $24 \mathrm{~h}$, plasmids from four randomly chosen clones were re-isolated for DNA sequencing.

\section{Site-directed mutagenesis for construction of pcDNA- LOCCS-T plasmid vectors}

According to the complimentary sequences with miR-93, mutagenesis primers were designed (F:TGATCTGACA TGGGAGGTCGAGGCC; R:CGATGCAACATGAGCCA CCGCGCCT) and used, with the pcDNA-LOCCS plasmid as template, for PCR amplification. Then, the pcDNA-LOCCS-T plasmid was constructed using the TaKaRa MutanBEST kit.

\section{Lentiviral vector construction, production, and cell infection}

The human LOCCS, miR-93, and MSI1-specific siRNA sequences were designed and synthesized by Shanghai Haike Corporation. The nonsilencing sequence 5 '-TTC TCCGAACGTGTCACGT-3' was used as a scrambled control. The LOCCS gene sequence is shown in the Additional file 1: S1. Oligonucleotides complementary to these sequences were synthesized and ligated into the pGCSIL-GFP vectors. Then the plasmids were amplified in E. coli DH5. For lentivirus generation, Lipofectamine 2000 (Invitrogen) was used to transfect recombinant pGCSIL-GFP, pHelper 1.0 and pHelper 2.0 vectors into $293 \mathrm{~T}$ cells. $48 \mathrm{~h}$ later, the lentiviral particles were harvested using 50,000 $\times g$ ultracentrifugation for $2 \mathrm{~h}$, and they are named as Lv-si-LOCCS, Lv-si-miR-93, Lv-siMSI1 and Lv-si-NC (negative control). For cell infection, $\mathrm{CD} 133^{+} / \mathrm{CD} 166^{+} / \mathrm{CD} 44^{+}$spheroid cells were incubated with lentiviruses at $50 \mathrm{MOI}$ for $48 \mathrm{~h}$, and stable clones were selected in the medium contained $10 \mathrm{mg} / \mathrm{mL}$ puromycin (Sigma-Aldrich, USA).

\section{Statistical analysis}

All data were statistically analyzed using Student's $t$ test or repeated one-way ANOVA with Dunnett post hoc test (GraphPad Prism 6, CA, USA). In all statistical analysis, $P$ value of $<0.05$ was considered significant.

\section{Results}

Primary human colon cancer cultures from fresh tumor tissue and colon cancer spheres formation

Fresh tumor tissue were digested and cultured in SSM. On the third day, some cells began to attach to the plastic support. After seven days, many cells grew in monolayers attached to the support and some of them began to divide. The primary cultured cells displayed an epithelial morphology, as observed using light microscopy (Fig. 1a). These cultured primary human colon cancer cells were then digested and plated in an SFM suspension culture system. During the initial selection phase, the majority of plated cells died off, and only a few colonies grew out. Spheres were observed on day 6 (Fig. 1b), and they accounted for $\sim 4 \%$ of the total number of cells on day 12 . The spheres also increased in volume over time.

\section{Analysis of the expression of surface markers CD133, CD166 and CD44 in primary colon cancer adherent and spheroid populations}

CD133, CD166 and CD44 have been reported to isolate CR-CSCs [2, 17, 18]. So we used the three surface markers to detect CR-CSCs in spheroid and also analyzed the expression of them. There was no significant difference in CD133 level between the adherent (8.4\%) and spheroid $(9.1 \%)$ cells $(P>0.05)$. The proportion of $\mathrm{CD}_{166}{ }^{+}$cells in the adherent cells was much smaller (10.2\%) than in the spheroid cells $(38.5 \%)(P<0.05)$. The proportion of CD $44^{+}$cells in the adherent cells was also much smaller (1.5\%) than in the spheroid cells (80.3\%) $(P<0.05)$. The CD133 positive cells were further analyzed for parallel expression of CD44 and CD166. A mean of $1.09 \%$ of cells were triple positive (CD133/ CD166/CD44) (Fig. 1c), and 5.73\% (CD133/CD44) and 2.12\% (CD133/CD166) were double positive.

Proliferation and differentiation capacity of colon cancerderived spheroid cells in vitro and tumor growth in vivo

We assessed the ability of proliferation of these primary cells in SFM. Sphere forming features were found in most primary tumor cells ( 9 of 10 cultures). These suspended spherical cells were observed within 7 days, and most of them survived in SFM for over 8 weeks. During prolonged propagation, $\sim 5 \%$ of cell spheres began to adhere to the plate and formed epithelial morphology with differentiation capacity. When growth factors were removed and the cells were exposed to $10 \%$ SSM, most of the cell spheres (>80\%) became adherent. As tumor spheres differentiated, cells migrated out and formed monolayer epithelial cells. 


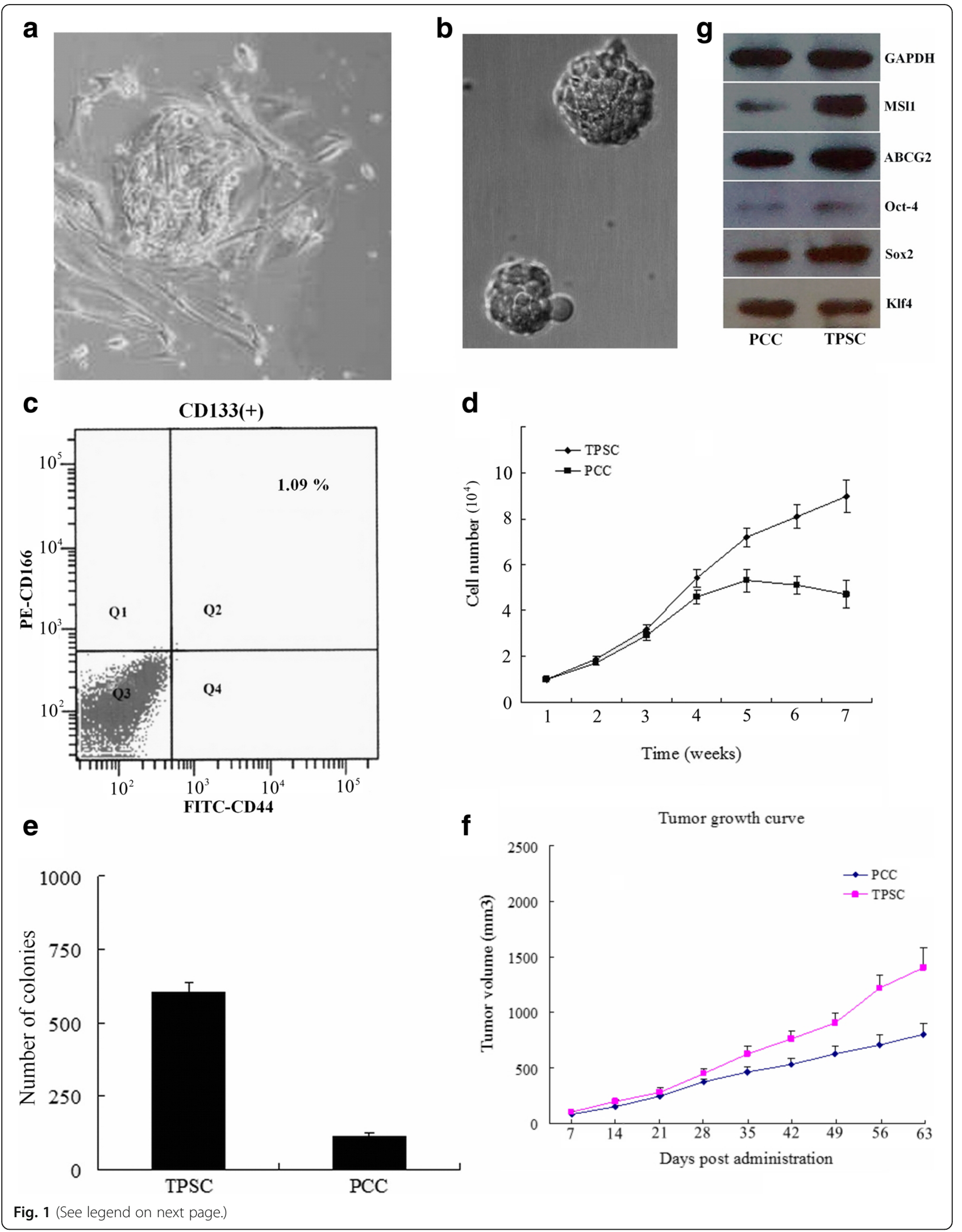


(See figure on previous page.)

Fig. 1 Generation, proliferative capacity, stem-cell markers of TPSC and their tumorigenicity in nude mice. a Primary cultured human colon cancer cells under light phase-contrast microscopy $(\times 200)$. b Spheres of human colon cancer cells in the SFM suspension culture system. $\mathbf{c}$ Expression of CD133, CD166 and CD44 stem cell surface markers in colon cancer spheroid cells. Flow cytometry dot plots showing that colon cancer sphere cells expressed high levels of CD166 and CD44 in SFM. Cancer sphere cells incubated with FITC-conjugated anti-CD44 and PE-conjugated anti-CD166 monoclonal antibodies. $\mathbf{d}$ Growth curves of TPSC and PCC. e Colony formation rates of TPSC and PCC. $\mathbf{f}$ Tumor xenografts in nude mice. The volume of tumors generated by $1 \times 10^{5}$ TPSC and PCC 63 days after injection. Left: TPSC; Right: PCC. $\mathbf{g}$ Expression of stem-cell markers in human colon cancer spheroid cells. Each experiment was performed in triplicate

We next evaluated the proliferative capacity of CD133 ${ }^{+} / \mathrm{CD} 166^{+} / \mathrm{CD}_{4} 4^{+}$spheroid cells (triple positive spheroid cells, TPSC) and found that TPSC in SFM had increased proliferative capacity compared with primary cultured cells (PCC) in SSM (Fig. 1d). The proliferation of colon cancer sphere cells was then assessed using coloning efficiency. TPSC were seeded on 24-hole plates (1000 cells per hole) and produced more numbers of spheres $(607 \pm 28)$ than PCC $(113 \pm 15)(P<0.05)$ (Fig. 1e).

For checking the tumorigenicity of cell spheroids, transplantation assays were performed and showed that $1 \times 10^{4}$ TPSC were competent to produce tumors, whereas the same number of PCC failed to produce visible tumors within 15 days. The tumor volume generated by $1 \times 10^{5}$ TPSC was significantly greater than that of the control group 63 days after injection $(P<0.05)$, indicating that TPSC have high tumorigenicity (Fig. 1f).

\section{Expression of stem-cell markers and chemotherapeutic drug resistance in tumor spheroid cells}

The expression levels of several stem cell markers (MSI1, Oct-4, Sox2, Klf4 and ABCG2) were detected in TPSC. As shown in Fig. 4, western blot showed that MSI1, Oct-4, Sox2 and ABCG2 had higher expression levels in TPSC than in PCC. However, Klf4 showed no obvious difference in expression levels between TPSC and PCC.

Multidrug resistance of TPSC to paclitaxel, adriamycin, etoposide, cytarabine, fluorouracil, cisplatin and mitomycin was examined in an Alamar blue assay. Compared with PCC, TPSC displayed a marked increase in resistance to these chemotherapeutic drugs. The resistance of TPSC to adriamycin, paclitaxel, mitomycin, etoposide, cisplatin, cytarabine and fluorouracil was 17.4, 13.9, 4.2, 3.0, 2.6, 2.0 and 1.5 folds higher than differentiated cell populations (Table 2). The results show that colon tumor spheroid cells have increased resistance to standard chemotherapy than differentiated cells.

\section{Expression of a novel IncRNA in colon cancer-derived spheroid cells}

In previous studies, we found the expression of a lncRNA (ENST00000414816, also referred to as long intergenic non-protein-coding RNA 1567; LINC01567) was significantly upregulated in colon cancer-derived spheroid cells (data not published). This lncRNA may play a key role in occurrence and progression of colon cancer. LINC01567 gene is located on chromosome 16 (positions 24,661,422$24,671,062$ on the reverse strand), contains three exons and produces one transcript (2907 bp) (Fig. 2a). (sequences in the Additional file 1: S1) We detected the expression levels of LINC01567 (hereafter referred to as LOCCS; lncRNA overexpressed in colon cancer stem cells) in 10 pairs of PCC and TPSC using quantitative PCR. The levels of LOCCS in TPSC were obviously increased relative to PCC (8 in 10 pairs; $P<0.05$ ) (Fig. $2 b$ ).

\section{The interaction between LOCCS and miR-93 in CD133 +/CD166+/CD44+ spheroid cells}

LOCCS was upregulated in TPSC and we concluded that it might play an important role in the proliferation and differentiation of CR-CRCs. Recently, some researchers have revealed that lncRNAs act as miRNA "sponges" to mitigate miRNA activities [19, 20]. Using lncRNA interaction analysis software (Starbase v2.0), we confirmed that LOCCS could bind with miR-93, and the binding region is shown in Fig. 2c. Three pENTR/U6-siLOCCS plasmids (Z1, Z2, and Z3) were constructed and transfected into TPSC to knock down the expression of LOCCS. (sequences in the Additional file 2: S2) Quantitative PCR indicated that miR-93 was upregulated as LOCCS decreased, and the Z2 plasmid was used for the following experiments (Fig. 2d).

To confirm the interaction between LOCCS and miR-93, we synthesized pGL3M-miR-93, pcDNA-LOCCS and pcDNA-LOCCS-T plasmids and transfected them into TPSC. (sequences in the Additional file 2: S2) In the

Table 2 Sensitivity of colon cancer spheroid cells and primary cultured cells to chemotherapeutic drugs

\begin{tabular}{llll}
\hline \multirow{2}{*}{ Drug } & \multicolumn{1}{l}{ C50 (mg/L) } & \\
\cline { 2 - 3 } & TPSC & PCC & Fold difference \\
\hline Adriamycin & $36.5 \pm 2.3^{* *}$ & $2.1 \pm 0.2$ & 17.4 \\
Paclitaxel & $32.0 \pm 2.4^{* *}$ & $2.3 \pm 0.3$ & 13.9 \\
Mitomycin & $0.93 \pm 0.04^{* *}$ & $0.22 \pm 0.02$ & 4.2 \\
Etoposide & $10.2 \pm 0.3^{* *}$ & $3.4 \pm 0.2$ & 3.0 \\
Cisplatin & $10.5 \pm 0.6^{*}$ & $4.1 \pm 0.3$ & 2.6 \\
Cytarabine & $27.7 \pm 1.7^{*}$ & $13.9 \pm 0.8$ & 2.0 \\
Fluorouracil & $50.5 \pm 4.1^{*}$ & $33.2 \pm 2.2$ & 1.5 \\
\hline
\end{tabular}

${ }^{*} P<0.01 ; * P<0.05 ;$ IC50: The half maximal inhibitory concentration 


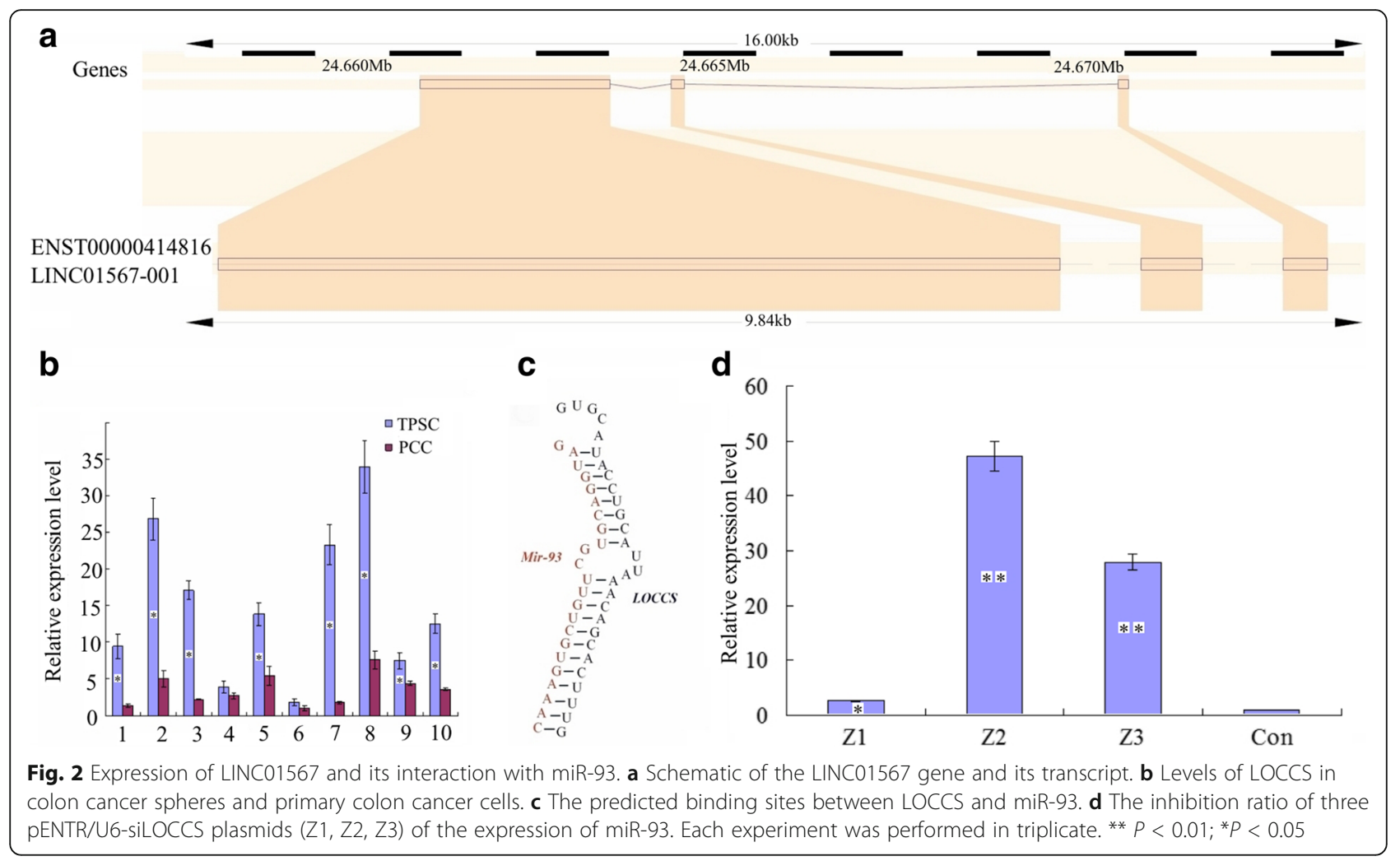

endogenous LOCCS assay, we transfected cells with various combinations of the three plasmids. The expression of the FLUC reporter was inhibited by endogenous LOCCS, as was the expression of miR-93 from pGLM-miR-93. However, when the endogenous LOCCS was degraded by siLOCCS transcribed from the pENTR/U6-siLOCCS plasmid, the inhibition of miR-93 by LOCCS was weakened, and thus FLUC levels were higher (A vs. C, B vs. C; $P<0.05$ ) (Table 3 ). When cells were cotransfected with pcDNA-LOCCS, miR-93 was inhibited by both endogenous and exogenous LOCCS, and, thus, the levels of miR-93 in this group were the lowest among the groups (D vs. F, D vs. E; $P<0.05$ ). In contrast, LOCCS-T transcribed from the pcDNA-LOCCS-T plasmid could not combine with miR-93. The miR-93 levels were similar to those of the group without exogenous LOCCS (E vs. F; $P>0.05$ ) (Table 3). The observation that if the binding sequence in LOCCS was mutated, it

Table 3 Dual luciferase reporter assays confirm the interaction between endogenous or exogenous LOCCS and miR-93

\begin{tabular}{|c|c|c|c|c|c|c|c|c|c|}
\hline \multirow[b]{2}{*}{ Group } & \multicolumn{9}{|c|}{ Endogenous LOCCS } \\
\hline & \multicolumn{3}{|l|}{ A } & \multicolumn{3}{|l|}{ B } & \multicolumn{3}{|l|}{ C } \\
\hline Value & 1 & 2 & 3 & 1 & 2 & 3 & 1 & 2 & 3 \\
\hline Firefly luciferase (RLU) & 360 & 342 & 368 & 283 & 271 & 302 & 410 & 409 & 426 \\
\hline Renilla luciferase (RLU) & 440 & 412 & 440 & 404 & 396 & 388 & 424 & 412 & 418 \\
\hline RLU & 0.82 & 0.83 & 0.84 & 0.7 & 0.68 & 0.78 & 0.97 & 0.99 & 1.02 \\
\hline \multirow[t]{2}{*}{ Average (mean \pm SD) } & \multicolumn{3}{|c|}{$0.83 \pm 0.01^{*}$} & \multicolumn{3}{|c|}{$0.72 \pm 0.05^{*}$} & \multicolumn{3}{|c|}{$0.99 \pm 0.03$} \\
\hline & \multicolumn{9}{|c|}{ Exogenous LOCCS } \\
\hline Group & \multicolumn{3}{|l|}{ D } & \multicolumn{3}{|l|}{$\mathrm{E}$} & \multicolumn{3}{|l|}{$\mathrm{F}$} \\
\hline Value & 1 & 2 & 3 & 1 & 2 & 3 & 1 & 2 & 3 \\
\hline Firefly luciferase (RLU) & 143 & 135 & 131 & 275 & 279 & 302 & 287 & 296 & 289 \\
\hline Renilla luciferase (RLU) & 340 & 392 & 364 & 376 & 360 & 412 & 396 & 360 & 376 \\
\hline RLU & 0.42 & 0.34 & 0.36 & 0.73 & 0.78 & 0.73 & 0.72 & 0.82 & 0.77 \\
\hline Average (mean \pm SD) & \multicolumn{3}{|c|}{$0.37 \pm 0.04^{*}$} & \multicolumn{3}{|c|}{$0.75 \pm 0.03$} & \multicolumn{2}{|c|}{$0.77 \pm 0.05$} & \\
\hline
\end{tabular}


could not combine with miR-93 confirmed that LOCCS acts on miR-93 directly.

We next investigated the effects of up or downregulated expression of LOCCS on the expression levels of HDAC8, TLE4, stratifin and MSI1 mRNA (Fig. 3a) and protein (Fig. 3b). LOCCS up-regulated the expressions of HDAC8 and TLE4 mRNAs, and down-regulated that of stratifin mRNA. LOCCS may play an important regulatory role in their expressions and the specific mechanism needs further exploration.

Knockdown of LOCCS suppresses CD133+/CD166+/CD44+ spheroid cells proliferation, invasion and migration in vitro and tumor growth in vivo

To further identify the role of LOCCS, it was knocked down (siLOCCS) or overexpressed (LOCCS-ox) in TPSC. The cells were counted for 7 weeks after seeding and we found that the LOCCS-ox and siLOCCS cells have different growth curves (Fig. 4a). The siLOCCS cells grew relatively slowly especially after sex weeks. LOCCS-ox cells showed the fastest growth rate, whereas untransfected TPSC cells displayed an intermediate growth rate. The proliferation of the cells was then detected using coloning efficiency. TPSC and LOCCS-ox cells produced more numbers of spheres $(625 \pm 31$ and $771 \pm 38$, respectively) than siLOCCS cells $(508 \pm 32)$ $(P<0.05)$ (Fig. 4b). Matrigel invasion and migration experiments showed a signifiant decrease of cell invasion and migration in siLOCCS-transfected group compared with the control and LOCCS-ox groups $(P<0.05)$ (Fig. 4c).

The xenograft tumor experiment revealed that the tumor spheroids had high tumorigenicity. $10^{4}$ colon cancer sphere cells could induce visible tumors, whereas the same number of primary cultured cells failed to produce visible tumors. The result showed the tumor spheroids were enriched in CSCs. Growth rates of the TPSC, LOCCS-ox, and siLOCCS cells and xenografts and tumor sizes of the three groups at 63 days are shown in Fig. 5 .

\section{MiR-93 and MSI1 mediated the tumor-suppressive effects of LOCCS knockdown on CD133+/CD166+/CD44+ spheroid cells}

To determine whether the tumor inhibition of LOCCS knockdown were mediated by miR-93, miR-93 upregulation by LOCCS knockdown was rescued using Lv-simiR-93 transfection before the evaluation of cell proliferation. Trypan blue and colony formation assays showed that the growth of TPSC in the Lv-si-LOCCS + Lv-simiR-93 group was increased compared with the Lv-siLOCCS + Lv-si-NC (control) group. In the Lv-si-LOCCS + Lv-si-miR-93 group, Lv-si-miR-93 rescued the suppression of Lv-si-LOCCS on cell growth (Fig. 6). This result suggested that miR-93 mediates the suppressive effects of LOCCS knockdown on colon cancer stem cell

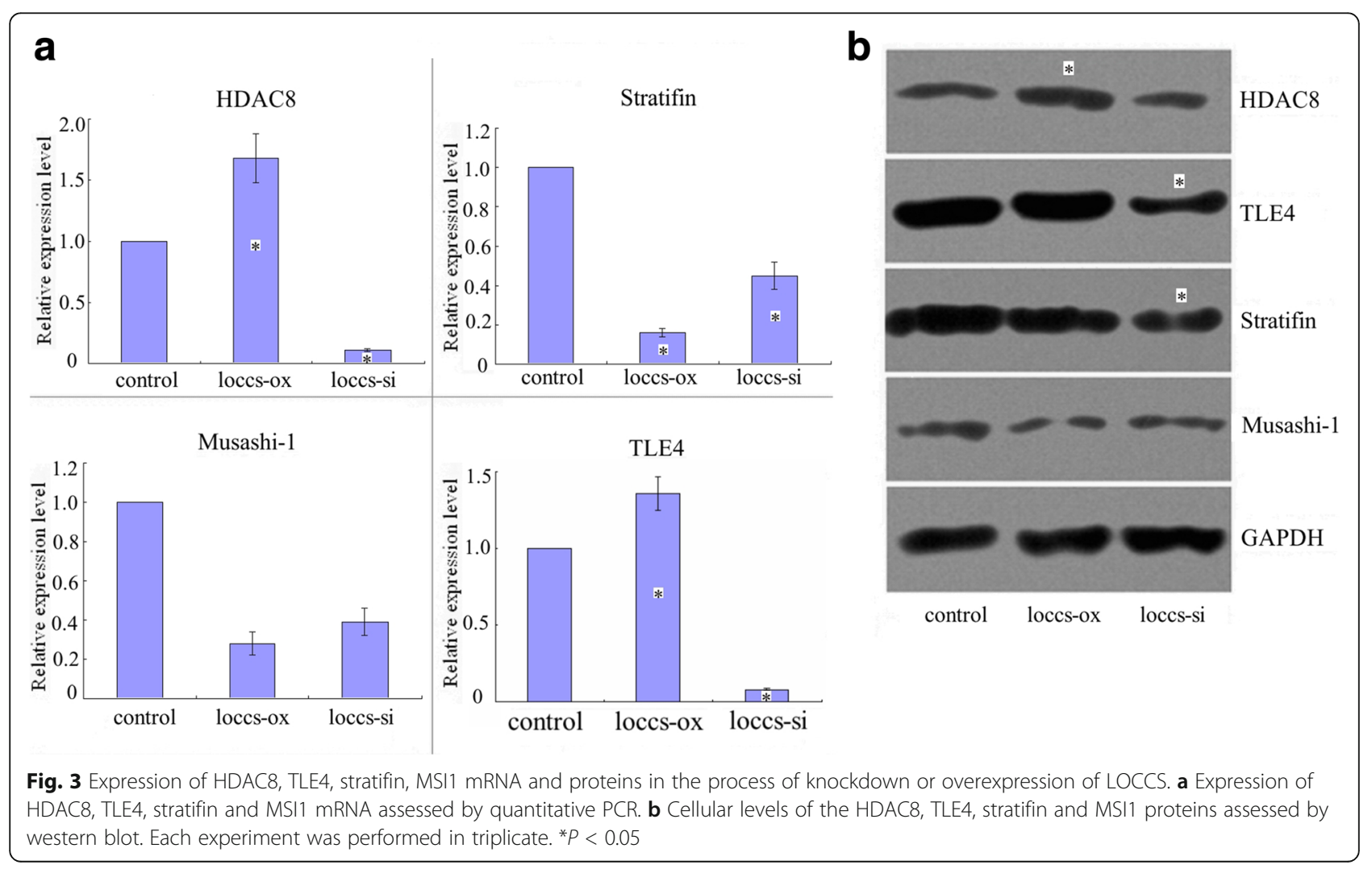




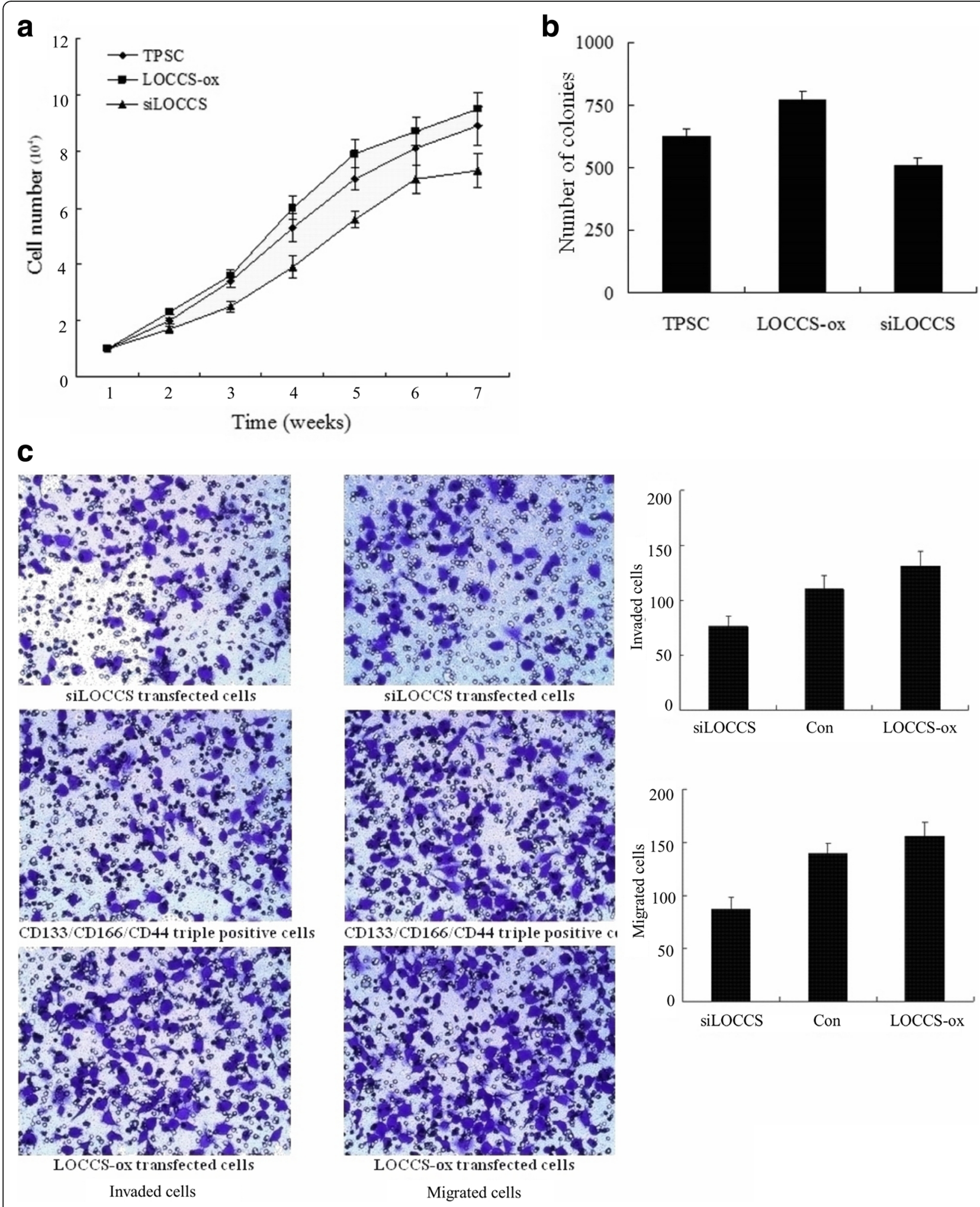

Fig. 4 Knockdown or overexpression of LOCCS influences proliferation, invasion and migration of human colon cancer stem cells. a Growth curves of TPSC transfected with the siLOCCS or LOCCS-ox plasmid. b Colony formation rates of TPSC transfected with the siLOCCS or LOCCS-ox plasmid. c Invasion and migration of TPSC transfected with the siLOCCS or LOCCS-ox plasmid. Each experiment was performed in triplicate 


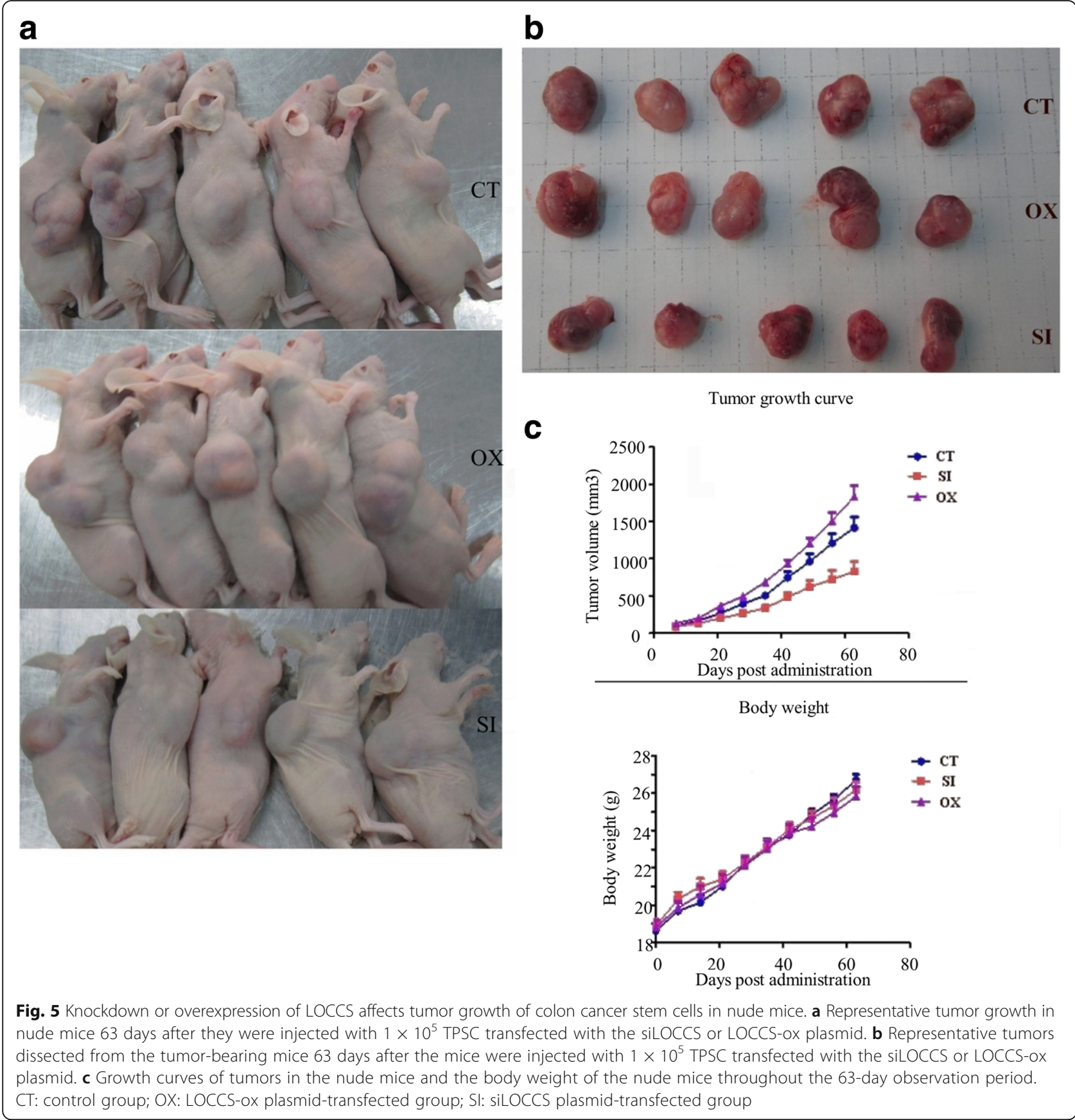

proliferation. Knockdown of MSI1 produced similar results to the above. In the Lv-si-LOCCS + Lv-si-MSI1 group, Lv-si-MSI1 also rescued the suppression of Lvsi-LOCCS on cell proliferation (Fig. 6).

\section{Discussion}

Identification and localization of CR-CSCs remains difficult owing to the lack of widely accepted cancer stem cell markers. Isolation and identification of CR-CSCs can be achieved based on many cell-surface markers, such as CD133, CD166, CD24, CD44, beta1 integrin/CD29,
ALDH-1, Lgr5, DCAMLK1, MSI1 and EpCAM [21, 22]. CD133, CD166 and CD44 are the important cell-surface markers which have recently been related to CR-CSCs.

$\mathrm{CD} 133$ is a $120-\mathrm{kDa}$ five-transmembrane domain glycoprotein, which express on neural, endothelial, normal primitive hematopoietic and epithelial cells [23]. In recent years, it has been regard as a CSC surface marker for brain tumors [24] and colon [2], pancreatic [25], liver [26], and prostate [27] cancers. CD166 plays a key role in T-cell activation and proliferation, angiogenesis, hematopoiesis and axon fasciculation [28]. Some researches have confirmed 

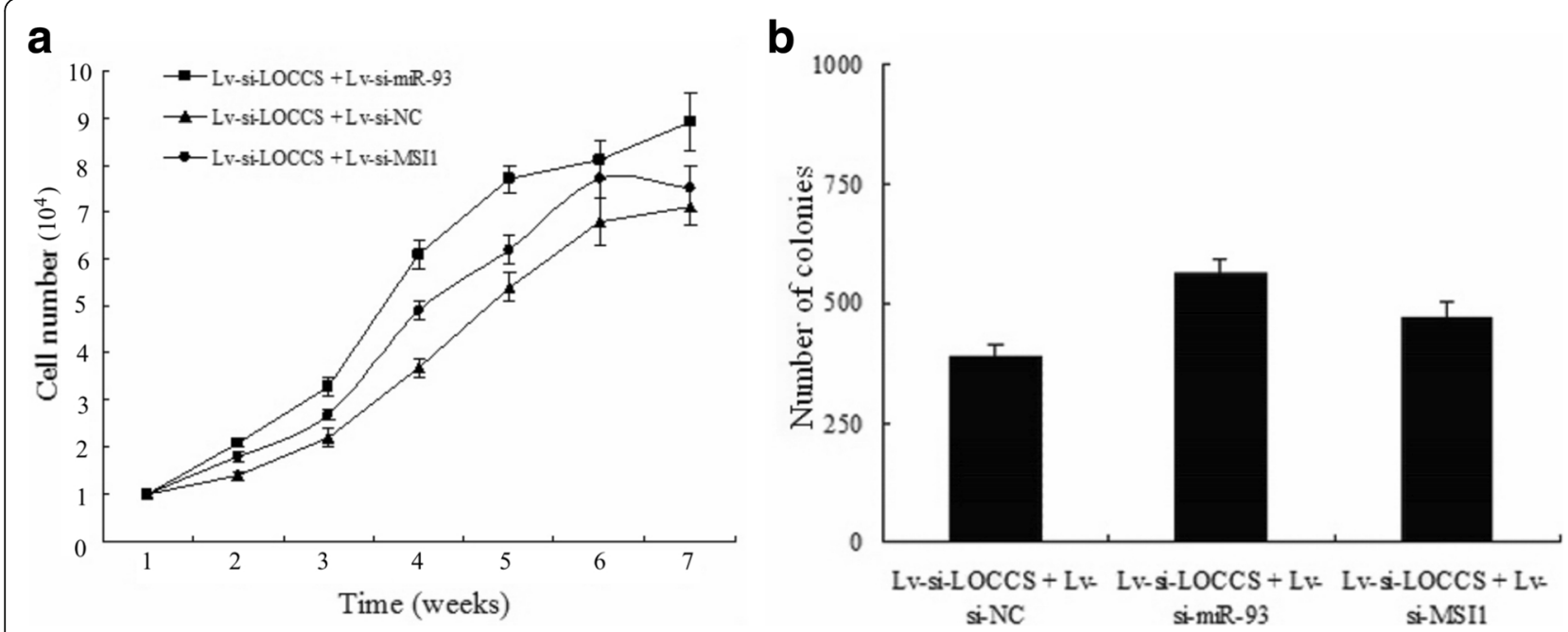

Fig. 6 MiR-93 and MSI1 mediated the tumor-suppressive effects of LOCCS knockdown on TPSC. a Growth curves of TPSC transfected with the Lv-si-LOCCS + Lv-si-miR-93 or Lv-si-LOCCS + Lv-si-MSI1 plasmids. b Colony formation rates of TPSC transfected with the Lv-si-LOCCS + Lv-si-miR-93 or LV-si-LOCCS + Lv-si-MSI1 plasmids. Each experiment was performed in triplicate

that CD166 enriches CSC-like cells in various cancers $[29,30]$. CD44 is an adhesion molecule which involves in many signal pathways [31]. This protein is also considered a stem-cell marker for cancers of the breast [32], pancreas [25], prostate [27], and colon [33] and for head and neck carcinoma [34]. High levels of the intestinal stem-cell marker MSI1 have been observed in CD $44^{+}$colon polyp cells [35].

In our research, we found that there was no obvious difference of CD133 expression in the adherent and spheroid cells isolated from human colon cancer tissue. However, the proportions of $\mathrm{CD} 166^{+}$and $\mathrm{CD} 44^{+}$cells in adherent cells were both much smaller than in spheroid cells. In other words, the levels of CD166 and CD44 were much higher in colon cancer spheroid cells. Other recent studies have found that $\mathrm{CD} 44^{+} \mathrm{CRC}$ cells display high tumorigenicity, especially combining $\mathrm{CD} 133^{+}$cells, whereas $\mathrm{CD} 44^{-}$cells do not form new tumors. Furthermore, CD44 can also be used in combination with CD166. A recent research showed that $\mathrm{CD} 44^{+} \mathrm{CD} 166^{+}$ colon cancer cells have greater ability to form xenografts in nude mice than $\mathrm{CD} 44^{+} \mathrm{CD} 166^{-}, \mathrm{CD} 44^{-} \mathrm{CD} 166^{+}$or $\mathrm{CD} 44^{-} \mathrm{CD} 166^{-}$cells $[36,37]$.

In the present study, the $\mathrm{CD} 133^{+}$subpopulations in spheroid cells were analyzed for parallel expression of CD166 and CD44. Most cells expressed only CD133 molecule and a mean of $1.09 \%$ of the cells were triple positive (CD133/CD166/CD44). The levels of CD133, CD166 and CD44 in spheroid cells was remarkable higher than in primary colon cancer cells, suggesting that the three molecules are mainly existed in undifferentiated tumor cells. We considered that a small amount of CSCs were present in primary cultured cells. They had the ability to form spheres and maintain an undifferentiated state. $\mathrm{CD} 133^{+} / \mathrm{CD} 166^{+} / \mathrm{CD} 44^{+}$spheroid cells possessed some characteristics as CSCs, including the ability to both proliferate and generate differentiated progeny, to resist chemotherapeutic drugs, and to produce xenografts in nude mice. We reveal that this marker combination $\left(\mathrm{CD} 133^{+} / \mathrm{CD} 166^{+} / \mathrm{CD} 44^{+}\right)$may be very useful in the identification of colon CSCs.

Recently, LncRNAs are considered as key modulators in CSC biology. For example, Jiao et al. [12] revealed that MALAT-1 acted as an oncogenic lncRNA in carcinoma of pancreas, and regulated CSC marker expression. MALAT-1 also increases ratio of pancreatic CSCs and multidrug resistance, maintains self-renewing capacity, and accelerates tumor angiogenesis. Wang et al. [13] confirmed that the expression of IncRNA HOTAIR in ovarian cancer tissues and SKOV3 $\mathrm{CD} 117^{+} \mathrm{CD} 44^{+} \mathrm{CSCs}$ increased obviously. In $\mathrm{CD} 117^{+} \mathrm{CD} 44^{+} \mathrm{CSCs}$, tumor growth and metastasis were significantly inhibited by downregulation HOTAIR expression.

Substantial evidence also confirms the important roles of miRNAs in regulating CSC biology. There are 11 upregulated and 8 down-regulated miRNAs in $\mathrm{CD} 133^{+}$ colon CSCs. These miRNAs have been observed to be associated with self-renewal and differentiation [16, 38]. In EpCAM-positive hepatocellular CSC, miR-181 was found to regulate differentiation by binding CDX2 and GATA6 [39]. In pancreatic carcinoma, CSCs show a signature of 210 miRNAs associated with proliferation and differentiation [40]. These researches show that miRNAs have an important role in regulating CSC proliferation, differentiation, and tumorigenesis. In our previous studies, we also found 46 dysregulated miRNAs in 
SW1116csc cells, 35 of which are overexpressed and 11 of which are downregulated. The downregulated miRNAs include miR-93 (16.7 times lower), and the upregulated expression level of miR-93 significantly inhibits cell growth and coloning efficiency of colon CSCs by negatively regulating mRNA and protein expression of HDAC8 and TLE4.

Dynamic expression of lncRNAs is involved in human carcinogenesis [41]. Considering the multiple targets of miRNAs, we hypothesized that there may be other lncRNAs as competing endogenous RNAs to regulate expression of key genes in CSCs. Competing endogenous RNA can act as a "sponge" to sequester miRNAs and therefore protect their target mRNAs from degradation $[19,20]$. In the former research, we found that miR-93 acts as a cancer suppressor in CSCs by targeting the HDAC8 and TLE4 genes [16]. Searching for IncRNAs with an miR-93 binding site, we found LOCCS. We hypothesized that LOCCS may act as a competitive RNA for miR-93 in CSCs. In this study, we revealed that knockdown of LOCCS induced the upregulation of miR-93. Using bioinformatics analysis and luciferase reporter assays, we elucidated the direct binding site of miR-93 in LOCCS.

Further, we examined the effects of LOCCS knockdown on the biological behaviors of colon CSCs and showed that knockdown of LOCCS suppressed colon CSC proliferation, invasion and migration. The results revealed that knockdown of LOCCS had tumor inhibitory effects in colon CSCs. Furthermore, the in vivo results also confirmed that knockdown of LOCCS inhibited tumor proliferation, elucidating that LOCCS down-regulation could be potentially applied in clinical colon cancer therapy.

The molecular mechanisms underlying LOCCS actions in colon CSCs remains unknown. LOCCS may be required for maintenance of the self-renewal state and the suppression of the specific genes associated with lineage differentiation. This hypothesis is supported by our study elucidating that LOCCS serves as a competitive endogenous RNA (sponge) for miR-93, thus releasing miR-93 inhibition of target molecules, including MSI1, HDAC8 and TLE4, in CSCs. The MSI1 knockdown assay showed that depression of MSI1 rescued the inhibition of Lv-si-LOCCS on cell proliferation, invasion and migration. The data suggests that the tumor inhibitory effects of LOCCS knockdown are also mediated by MSI1 in TPSC.

As a RNA binding protein, MSI1 has important function to regulate proliferation and differentiation of stem or precursor cells [42]. It can inhibit translation of target mRNAs by binding to the 3'UTR of the target mRNA [43]. By downregulating APC, p $21^{\text {WAF-1 }}$ and NUMB, MSI1 positively regulates the Notch and Wnt signaling pathways [44-46]. It has recently become clear that MSI1 also binds to the 3'UTR of other mRNAs, which may involve in cell renewal, differentiation, apoptosis, and cell cycle control, and protein modification controlled by MSI1 have been identified [47]. From the above results, we conceive that LOCCS may regulate the expression of HDAC8 and TLE4 through miR-93, and it may also take part in the Notch and Wnt signaling pathways through MSI1. In this way, LOCCS may modulate colon cancer stem cell proliferation and differentiation, resistance to chemotherapeutic drugs, and ability to generate tumor xenografts.

\section{Conclusions}

In the study, a new highly tumorigenic cell was identified from human colon adenocarcinomas. This kind of cell was isolated and purified using surface markers CD133, CD166, and CD44 and displayed some characteristics of stem cells. We have also shown for the first time that LOCCS expression is upregulated in colon CSCs. Knockdown of LOCCS reduced cell renewal, invasion and migration as well as reducing generation of tumor xenografts. Furthermore, miR-93 and MSI1 mediated the tumor suppression of LOCCS knockdown. There was reciprocal repression between LOCCS and miR-93 that mechanistic investigations suggested are attributable to direct binding of miR-93 by LOCCS. Taken together, our study elucidate that the IncRNA LOCCS may be a new modulator of human colon CSCs, which can exercise its functions by inhibiting miR-93 expression. Further researches of LOCCS may provide a new target for therapeutic strategies of colon cancer.

\section{Additional files}

Additional file 1: Sequences of long intergenic non-protein-coding RNA 1567 (LOCCS) (DOC 27 kb)

Additional file 2: Sequences of pENTR/U6-Z1, pENTR/U6-Z2, pENTR/U6-Z3, pGL3M-miR-93, pCDNA-LOCCS and pCDNA-LOCCS-T plasmids (DOC 245 kb)

\section{Abbreviations \\ CRC: colorectal carcinoma; CR-CSCs: CRC stem cells; CSCs: cancer stem cells; FITC: fluorescein isothiocyanate; FLUC: firefly luciferase; \\ GAPDH: glyceraldehyde-3-phosphate dehydrogenase; IC50: 50\% reduction in cell viability; LINC01567: long intergenic non-protein-coding RNA 1567; IncRNAs: long non-coding RNAs; LOCCS: IncRNA overexpressed in colon cancer stem cells; miR-93: microRNA-93; MSI1: musashi-1; PBS: phosphate- buffered saline; PCC: primary cultured cells; PE: phycoerythrin; SFM: serum- free medium; siRNA: small interfering RNA; SSM: serum-supplemented medium; TPSC: triple positive spheroid cells}

\section{Acknowledgements}

Not Applicable.

\section{Funding}

This research was funded by the National Natural Science Foundation of China (NO:81101617). The funder did not participate in completion the experiments and publication of the results. 


\section{Availability of data and materials}

The dataset supporting the conclusions of the manuscript is available upon request. Please contact Prof. Jian Zou (apollozou@hotmail.com).

\section{Authors' contributions}

JZ designed the research. XY cultured cells and performed PCR. LM performed animal experiment and statistical analyses. JD performed cell proliferation assay and western blot. JZ performed plasmid transfection and dual luciferase reporter assay, analyzed and interpreted results, and prepared the article. The final manuscript was approved by all authors.

\section{Ethics approval and consent to participate}

The study protocol was approved by the Clinical Research Ethics Committee of Huadong Hospital. Tumorous colon tissues were collected from patients undergoing colon cancer surgery at Huadong Hospital. Written informed consents were obtained from all patients. All animal experiments were approved by the Institutional Committee for Animal Research of Fudan University.

\section{Consent for publication}

Not Applicable.

\section{Competing interests}

The authors declare that they have no competing interests.

\section{Publisher's Note}

Springer Nature remains neutral with regard to jurisdictional claims in published maps and institutional affiliations.

\section{Author details}

'Department of Gastroenterology, Huadong Hospital Affiliated to Fudan University, West Yan'an Road 221, Shanghai 200040, China. ${ }^{2}$ Drug Clinical Trial Organization Office, Huadong Hospital Affiliated to Fudan University, Shanghai 200040, China.

Received: 6 June 2017 Accepted: 30 October 2017 Published online: 06 November 2017

\section{References}

1. Jemal A, Bray F, Center MM, Ferlay J, Ward E, Forman D. Global cancer statistics. CA Cancer J Clin. 2011:61:69-90.

2. Ricci-Vitiani L, Lombardi DG, Pilozzi E, Biffoni M, Todaro M, Peschle C, et al. Identification and expansion of human colon-cancer-initiating cells. Nature. 2007:445:111-5

3. Mittal S, Mifflin R, Powell DW. Cancer stem cells: the other face of Janus. Am J Med Sc. 2009;338:107-12

4. Scopelliti A, Cammareri P, Catalano V, Saladino V, Todaro M, Stassi G. Therapeutic implications of cancer initiating cells. Expert Opin Biol Ther. 2009:9:1005-16.

5. Guttman M, Donaghey J, Carey BW, Garber M, Grenier JK, Munson G, et al. lincRNAs act in the circuitry controlling pluripotency and differentiation. Nature. 2011;477:295-300.

6. Guttman M, Amit I, Garber M, French C, Lin MF, Feldser D, et al. Chromatin signature reveals over a thousand highly conserved large non-coding RNAs in mammals. Nature. 2009;458:223-7.

7. Huarte M, Guttman M, Feldser D, Garber M, Koziol MJ, Kenzelmann-Broz D, et al. A large intergenic noncoding RNA induced by p53 mediates global gene repression in the p53 response. Cell. 2010;142:409-19.

8. Mohammad F, Pandey GK, Mondal T, Enroth S, Redrup L, Gyllensten U, et al. Long noncoding RNA-mediated maintenance of DNA methylation and transcriptional gene silencing. Development. 2012;139:2792-803.

9. Cheetham SW, Gruhl F, Mattick JS, Dinger ME. Long noncoding RNAs and the genetics of cancer. Br J Cancer. 2013;108:2419-25.

10. Spizzo R, Almeida MI, Colombatti A, Calin GA. Long non-coding RNAs and cancer:a new frontier of translational research? Oncogene. 2012:31:4577-87.

11. Wang P, Ren Z, Sun P. Overexpression of the long non-coding RNA MEG3 impairs in vitro glioma cell proliferation. J Cell Biochem. 2012;113:1868-74.

12. Jiao F, Hu H, Han T, Yuan C, Wang L, Jin Z, et al. Long noncoding RNA MALAT-1 enhances stem cell-like phenotypes in pancreatic cancer cells. Int J Mol Sci. 2015;16:6677-93

13. Wang J, Chen D, He X, Zhang Y, Shi F, Wu D, et al. Downregulated lincRNA HOTAIR expression in ovarian cancer stem cells decreases its tumorgeniesis and metastasis by inhibiting epithelial-mesenchymal transition. Cancer Cell Int. 2015;15:24.

14. Eades G, Zhang YS, Li QL, Xia JX, Yao Y, Zhou Q. Long non-coding RNAs in stem cells and cancer. World J Clin Oncol. 2014;5:134-41.

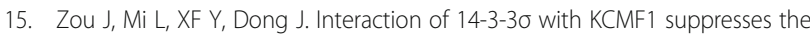
proliferation and colony formation of human colon cancer stem cells. World J Gastroenterol. 2013;19:3770-80.

16. XF Y, Zou J, Bao ZJ, Dong J. miR-93 suppresses proliferation and colony formation of human colon cancer stem cells. World J Gastroenterol. 2011;17:4711-7

17. O'Brien CA, Pollett A, Gallinger S, Dick JEA. Human colon cancer cell capable of initiating tumour growth in immunodeficient mice. Nature. 2007:445:106-10.

18. Dalerba P, Dylla SJ, Park IK, Liu R, Wang X, Cho RW, et al. Phenotypic characterization of human colorectal cancer stem cells. Proc Natl Acad Sci U S A. 2007:104:10158-63.

19. Loewer S, Cabili MN, Guttman M, Loh YH, Thomas K, Park IH, et al. Large intergenic non-coding RNA-RoR modulates reprogramming of human induced pluripotent stem cells. Nat Genet. 2010;42:1113-7.

20. Wang $Y, X u Z$ Z, Jiang J, Xu C, Kang J, Xiao L, et al. Endogenous miRNA sponge lincRNA-RoR regulates Oct4, Nanog, and Sox2 in human embryonic stem cell self-renewal. Dev Cell. 2013;25:69-80.

21. Vaiopoulos AG, Kostakis ID, Koutsilieris M, Papavassiliou AG. Colorectal cancer stem cells. Stem Cells. 2012;30:363-71.

22. Thenappan A, Li Y, Shetty K, Johnson L, Reddy EP, Mishra L. New therapeutics targeting colon cancer stem cells. Curr Colorectal Cancer Rep. 2009;5:209.

23. Mizrak D, Brittan M, Alison MR. CD133: molecule of the moment. J Pathol 2008;214:3-9.

24. Singh SK, Clarke ID, Terasaki M, Bonn VE, Hawkins C, Squire J, et al. Identification of a cancer stem cell in human brain tumors. Cancer Res. 2003:63:5821-8.

25. Lee CJ, Dosch J, Simeone DM. Pancreatic cancer stem cells. J Clin Oncol. 2008:26:2806-12

26. Suetsugu A, Nagaki M, Aoki H, Motohashi T, Kunisada T, Moriwaki H. Characterization of CD133+ hepatocellular carcinoma cells as cancer stem/progenitor cells. Biochem Biophys Res Commun. 2006;351:820-4

27. Collins AT, Berry PA, Hyde C, Stower MJ, Maitland NJ. Prospective identification of tumorigenic prostate cancer stem cells. Cancer Res. 2005;65:10946-51.

28. Jia G, Wang X, Yan M, Chen W, Zhang P. CD166-mediated epidermal growth factor receptor phosphorylation promotes the growth of oral squamous cell carcinoma. Oral Oncol. 2016:59:1-11.

29. Levin TG, Powell AE, Davies PS, Silk AD, Dismuke AD, Anderson EC, et al Characterization of the intestinal cancer stem cell marker CD166 in the human and mouse gastrointestinal tract. Gastroenterology. 2010;139:2072-82.

30. Jiao J, Hindoyan A, Wang S, Tran LM, Goldstein AS, Lawson D, et al. Identification of CD166 as a surface marker for enriching prostate stem/ progenitor and cancer initiating cells. PLoS One. 2012;7:42564.

31. Schmidt DS, Klingbeil $P$, SchnöLzer M, ZöLler M. CD44 variant isoforms associate with tetraspanins and EpCAM. Exp Cell Res. 2004;297:329-47.

32. Al-Haij M, Wicha MS, Benito-Hernandez A, Morrison SJ, Clarke MF. Prospective identification of tumorigenic breast cancer cells. Proc Natl Acad Sci U S A. 2003;100:3983-8.

33. Horst D, Kriegl L, Engel J, Kirchner T, Jung A. Prognostic significance of the cancer stem cell markers CD133, CD44, and CD166 in colorectal cancer. Cancer Investig. 2009;27:844-50.

34. Prince ME, Sivanandan R, Kaczorowski A, Wolf GT, Kaplan MJ, Dalerba P, et al. Identification of a subpopulation of cells with cancer stem cell properties in head and neck squamous cell carcinoma. Proc Natl Acad Sci U S A. 2007;104:973-8.

35. Schulenburg A, Cech P, Herbacek I, Marian B, Wrba F, Valent $P$, et al. CD44-positive colorectal adenoma cells express the potential stem cell markers musashi antigen (msi1) and ephrin B2 receptor (EphB2). J Pathol. 2007:213:152-60.

36. Wang C, Xie J, Guo J, Manning HC, Gore JC, Guo N. Evaluation of CD44 and CD133 as cancer stem cell markers for colorectal cancer. Oncol Rep. 2012;28:1301-8

37. Langan RC, Mullinax JE, Raiji MT, Upham T, Summers T, Stojadinovic A, et al. Colorectal cancer biomarkers and the potential role of cancer stem cells. J Cancer. 2013:4:241-50

38. Zhang H, Li W, Nan F, Ren F, Wang H, Xu Y, et al. MicroRNA expression profile of colon cancer stem-like cells in HT29 adenocarcinoma cell line. Biochem Biophys Res Commun. 2011;404:273-8. 
39. Meng F, Glaser SS, Francis H, DeMorrow S, Han Y, Passarini JD, et al. Functional analysis of microRNAs in human hepatocellular cancer stem cells. J Cell Mol Med. 2012;16:160-73.

40. Jung DE, Wen J, Oh T, Song SY. Differentially expressed microRNAs in pancreatic cancer stem cells. Pancreas. 2011;40:1180-7.

41. Poliseno L, Salmena L, Zhang J, Carver B, Haveman WJ, Pandolfi PPA. Coding-independent function of gene and pseudogene mRNAs regulates tumor biology. Nature. 2010;465:1033-8.

42. Okano H, Kawahara H, Toriya M, Nakao K, Shibata S, Imai T. Function of RNA-binding protein Musashi-1 in stem cells. Exp Cell Res. 2005;306:349-56.

43. Kawahara H, Imai T, Imataka H, Tsujimoto M, Matsumoto K, Okano H. Neural RNA-binding protein Musashi1 inhibits translation initiation by competing with elF4G for PABP. J Cell Biol. 2008;181:639-53.

44. Imai T, Tokunaga A, Yoshida T, Hashimoto M, Mikoshiba K, Weinmaster G, et al. The neural RNA-binding protein Musashi1 Translationally regulates mammalian numb gene expression by interacting with its mRNA. Mol Cell Biol. 2001;21:3888-900.

45. Battelli C, Nikopoulos GN, Mitchell JG, Verdi JM. The RNA-binding protein Musashi-1 regulates neural development through the translational repression of p21WAF-1. Mol Cell Neurosci. 2006;31:85-96.

46. Spears $E$, Neufeld KL. Novel double-negative feedback loop between adenomatous polyposis coli and Musashi1 in colon epithelia. J Biol Chem. 2011;286:4946-50.

47. de Sousa Abreu R, Sanchez-Diaz PC, Vogel C, Burns SC, Ko D, Burton TL, et al. Genomic analyses of musashi1 downstream targets show a strong association with cancer-related processes. J Biol Chem. 2009;284:12125-35.

\section{Submit your next manuscript to BioMed Central and we will help you at every step:}

- We accept pre-submission inquiries

- Our selector tool helps you to find the most relevant journal

- We provide round the clock customer support

- Convenient online submission

- Thorough peer review

- Inclusion in PubMed and all major indexing services

- Maximum visibility for your research

Submit your manuscript at www.biomedcentral.com/submit

C) Biomed Central 